\title{
EFFECTS OF AMARANTHUS SPINOSUS (GREEN) LEAF MEAL ON THE PERFORMANCE OF HUBBARD BROILER CHICKS
}

\author{
Emmanuel Obioha Ahaotu $^{1 *}$, Kenedy Chigozie Okorie ${ }^{2}$, Albayomy Akinfemi ${ }^{3}$ \\ ${ }^{1}$ Department of Animal Production and Health Technology, Imo State Polytechnic, \\ Umuagwo, P.M.B. 1472, Owerri, Nigeria \\ ${ }^{2}$ Department of Animal Science and Fisheries, Imo State University, Owerri, Nigeria \\ ${ }^{3}$ Department of Animal Science, Nasarawa State University, Nasarawa, Nigeria \\ *emmaocy@yahoo.com
}

\begin{abstract}
A b s t r a c t: A twenty eight day feeding trial was conducted with one hundred and twenty 7-day old Hubbard 2000 broiler chicks to study the effects of green leaf (Amaranthus spinosus) as a dietary energy source. Amaranthus spinosus leaves dried and ground were used to each replace wheat offal in the following dietary levels: $0 \%, 2.5 \%, 5 \%$, $7.5 \%$ and $10 \%$, respectively. The chicks were divided into five treatment groups, each group replicated four times at the rate of five chicks per replicate. The performance and organ weight characteristics were evaluated. Amaranthus spinosus leaf meals improved the mean feed intake, body weight gain and live weight of broilers. The performance of broilers in the Amaranthus spinosus leaf meal based diets was inferior to the control. Amaranthus spinosus caused significant proportionate growth in \% daily weight $(\mathrm{p}<0.05)$ and carcass evaluation $(\mathrm{p}<0.05)$. Utilization of Amaranthus spinosus significantly increased $(\mathrm{p}<0.05)$ the $\%$ live weight of the abdominal fat thus improving the nutritive value of the meat. The aim of this research was to determine the response of Amaranthus spinosus leaf meal on the organ weight characteristics and performance of Hubbard starter broilers.
\end{abstract}

Key words: Hubbard broiler chicks; Amaranthus spinosus; leaf meal; wheat offal; performance; organ weight

\section{ЕФЕКТИ НА БРАШНОТО ОД ЛИСТОТ (ЗЕЛЕН) НА AMARANTHUS SPINOSUS ВРЗ ПЕРФОРМАНСИТЕ НА БРОЈЛЕРСКИТЕ ПИЛИЬА ОД ХИБРИДОТ ХАБАРД}

\begin{abstract}
А п с т р а к т: Заради проучување на ефектот на зелените листови на Amaranthus spinosus како диететски извор на енергија, изведено е дваесет и осум-дневно испитување врз 120 бројлерски пилиња од хибридот хабард, стари 7 дена. Беа употребени исушени и сомелени листови од Amaranthus spinosus како замена за пченичните трици, со следните диететски нивоа: $0 \%, 2,5 \%, 5 \%, 7,5 \%$ и $10 \%$. Пилињата беа поделени во пет групи, при што секоја група беше реплицирана четири пати, пет пилиња по репликат. Беа оценувани перформансите и тежината на органите. Крмното брашно од листови на Amaranthus spinosus го подобри просечниот внес на храната, порастот на телесната тежина и живата мера на бројлерите. Перформансите на бројлерите кои беа на исхрана базирана врз крмно брашно од листови на Amaranthus spinosus беа инфериорни во однос на контролата. Amaranthus spinosus предизвика значителен пропорционален пораст во \% дневна тежина ( $\mathrm{p}<0,05)$ и оцената на трупот ( $\mathrm{p}<0,05)$. Утилизацијата на Amaranthus spinosus значително го зголеми $(\mathrm{p}<0,05)$ процентот на живата тежина на абдоминалната маснотија, на тој начин подобрувајќи ја хранливата вредност на месото. Целта на ова истражување беше да се утврди ефектот на крмното брашно од листови на Amaranthus spinosus врз тежината на органите и перформансите на бројлерите од хибридот Hubbard.
\end{abstract}

Клучни зборови: бројлерски пилиња хабард; крмно брашно од листови на Amaranthus spinosus; пченични трици; перформанси; тежина на органите

\section{INTRODUCTION}

In poultry production, feed cost claims the largest share of the total expenses involved in the production process. Feed alone accounts for over
$75 \%$ of the total cost of production, out of which $50 \%$ is expended on protein and energy sources (Ahaotu et al., 2013a, 2016a and b). An approach that seems to have the greatest potential products is 
the evaluation of the alternative feed sources including Amaranthus spinosus. It was felt that Amaranthus spinosus could be an untapped energy source that can substitute wheat offal, which is currently the plague and limiting factor in the expansion of poultry and poultry feed industry. The utilization and incorporation of Amaranthus spinosus into broiler feed will go a long way in increasing broiler production, conserve the Nations Foreign exchange used in importation of cereals and finally reduce the pressure on the major energy source in broiler rations.

Several factors have been generally identified as limiting to the utilization or high incorporation of non-conventional feedstuffs in livestock feed. These include low protein content, high fibre, amino acid imbalance and presence of anti-nutritional factors (Ahaotu et al., 2018a and b). Anti-nutritional factors have significant negative effects on livestock production. These effects include reduction in palatability, digestibility and utilization of ration, intoxication of different classes of livestock, resulting in mortality or decreased production of animal and reduction in the quality of meat, egg, and milk products due to the presence of hazardous residues (Akinfemi et al., 2014; Ononiwu et al., 2017; Ahaotu et al., 2017). Alternative sources of feed ingredients should be found which are not utilized by the human population and which, at present, might not have been found wider use in animal feeding (Ahaotu et al., 2015; Okonkwo and Ahaotu, 2014).

\section{MATERIALS AND METHODS}

The study was carried at the Teaching and Research Farm (Poultry Unit) of the Department of Animal Production and Health Technology, Imo State Polytechnic, Umuagwo, Ohaji, Nigeria. The site is situated between longitudes $7^{\circ} 0^{1} 06^{11}$ and $7^{\circ}$ $03^{1} 00^{11} \mathrm{E}$ and latitudes $5^{\circ} 28^{1} 00^{11}$ and $5^{\circ} 30^{1} 00^{11} \mathrm{~N}$ in the humid tropical West Africa (IMLS, 2009).

\section{ANIMALS, DIETS AND EXPERIMENTAL DESIGN}

A total of one hundred and twenty (120) seven days old Hubbard 2000 broiler chicks were randomly allotted to five experimental treatments in a completely randomized design. The chicks were divided into five treatment groups, each group replicated four times at the rate of five chicks per replicate. The experimental diets and water were provided ad libitum throughout the experimental period that lasted for four weeks. Prior to the beginning of the experiments, birds were weighed to obtain their initial body weight and subsequently on a weekly basis. The performance parameters measured were feed intake, body weight gain and feed conversion ratio.

\section{Table 1}

Chemical composition of the experimental diet

\begin{tabular}{lccccc}
\hline \hline Ingredients & $\mathrm{T}_{1}$ & $\mathrm{~T}_{2}$ & $\mathrm{~T}_{3}$ & $\mathrm{~T}_{4}$ & $\mathrm{~T}_{5}$ \\
\hline Amaranthus spinosus & 0.00 & 2.5 & 5.0 & 7.5 & 10.0 \\
Wheat offal & 10.0 & 7.5 & 5.0 & 2.5 & 0.00 \\
Fish meal & 3.0 & 3.0 & 3.0 & 3.0 & 3.0 \\
Groundnut cake & 10.0 & 10.0 & 10.0 & 10.0 & 10.0 \\
Soya-bean meal & 22 & 22 & 22 & 22 & 22 \\
Maize & 40 & 40 & 40 & 40 & 40 \\
Palm kernel cake & 10.0 & 10.0 & 10.0 & 10.0 & 10.0 \\
Bone meal & 4.29 & 4.29 & 4.29 & 4.29 & 4.29 \\
Lysine & 0.1 & 0.1 & 0.1 & 0.1 & 0.1 \\
Dl-methionine & 0.06 & 0.06 & 0.06 & 0.06 & 0.06 \\
Premix (broiler) & 0.25 & 0.25 & 0.25 & 0.25 & 0.25 \\
Common salt & 0.3 & 0.3 & 0.3 & 0.3 & 0.3 \\
Total & 100 & 100 & 100 & 100 & 100 \\
\hline Chemical composition nutrients & & \\
\hline \hline & 23.20 & 22.50 & 21.80 & 21.10 & 20.40 \\
Crude protein & 3.40 & 3.86 & 3.96 & 4.34 & 4.36 \\
Crude fiber & 3.61 & 3.73 & 3.76 & 3.89 & 3.94 \\
Ether extract & 2809.9 & $2805 . .9$ & 2802.2 & 2798.5 & 2794.7 \\
ME/kcal/kg) & & & & & \\
\hline \hline
\end{tabular}

*2.5 kg Premix/tonne contain: Vitamin A 10,000 I.U; Vitamin D3 2000,000 I.U, Vitamin E 12,000 I.U. Vitamin K 2.5 gm, Thiamine 1.5 g, Riboflavin 5 g, Pyriboflavin (B6) $1.5 \mathrm{~g}$, Vitamin B12 $10 \mathrm{mg}$, Biotin $2 \mathrm{mg}$, Niacin $15 \mathrm{~g}$, Pantothenic acid $5 \mathrm{~g}$, Zinc $50 \mathrm{~g}$, Iron $25 \mathrm{~g}$, Copper 5 g, Iodine 1.4 g, Selenium 100 mg, Cobalt 300 mg, B. H. T. 125 g.

\section{Carcass characteristics}

At the end of the feeding trial, 3 birds from each replicate group were randomly taken; fasted over night and slaughtered by severing the jugular vein. The birds were dressed and eviscerated. During the evisceration, the internal organs and other parts were carefully removed and weighed. Their weights were expressed as a percentage of the dressed carcass weight. 


\section{Data analysis}

Data analysis was done using analysis of variance technique of Steel and Torrie (1980) while significant differences in means were separated using the method of Duncan's Multiple Range Test as outlined by Gordon and Gordon (2004).

\section{Management}

Each experimental group was offered its corresponding diet ad libitum and they had free access to water. Hygienic conditions were followed to keep the drinkers and feeders always clean. Feeds offered were weighed. At the end of the week the residues were weighed and deduced from the introduced amounts. The chickens were weighed weekly before being given food. All mortality cases were registered.

\section{RESULTS AND DISCUSSION}

Effect of Amaranthus spinosus leaf meal on the performance of Hubbard broiler chicks is presented in Table 2. There was significant $(p<0.05)$ variations in body weight gain and feed conversion ratio of the chicks. Inclusion of higher levels of Amaranthus spinosus leaf meal was accompanied by a significant $(\mathrm{p}<0.05)$ improvement in final body weight and daily weight gain of Hubbard broiler chicks.

Table 2

\begin{tabular}{|c|c|c|c|c|c|c|}
\hline Parameters & $\mathrm{T} 1$ & $\mathrm{~T} 2$ & $\mathrm{~T} 3$ & $\mathrm{~T} 4$ & T5 & SEM \\
\hline Initial body weight (g) & 55 & 54.10 & 54.40 & 54.80 & 55.70 & $0.03^{\mathrm{ns}}$ \\
\hline Final body weight (g) & $492.4^{\mathrm{a}}$ & $382.2^{\mathrm{b}}$ & $356.9^{\mathrm{c}}$ & $336.7^{\mathrm{d}}$ & $325.6^{\mathrm{a}}$ & $3.00^{*}$ \\
\hline Body weight gain (g) & 34.57 & 31.28 & 30.85 & 30.20 & 28.50 & $2.98^{*}$ \\
\hline Daily weight gain (g) & $25.84^{\mathrm{a}}$ & $28.15^{\mathrm{b}}$ & $29.39^{\mathrm{b}}$ & $31.55^{\mathrm{c}}$ & $34.32^{\mathrm{d}}$ & $0.29^{*}$ \\
\hline Daily feed intake (g) & 48.21 & 49.71 & $50.96^{\mathrm{a}}$ & $53.03^{\mathrm{a}}$ & $58.26^{\mathrm{b}}$ & $3.65^{\mathrm{n}}$ \\
\hline Feed conversion ratio & $2.28^{\mathrm{a}}$ & $2.49^{\mathrm{b}}$ & $2.61^{\mathrm{c}}$ & $2.91^{\mathrm{d}}$ & $3.12^{\mathrm{d}}$ & $0.93^{*}$ \\
\hline Feed cost & $201.16^{\mathrm{e}}$ & $195.6^{\mathrm{d}}$ & $184.48^{\mathrm{c}}$ & $178.92^{b}$ & 171.44- & $2.17^{*}$ \\
\hline
\end{tabular}

$\mathrm{a}, \mathrm{b}, \mathrm{c}, \mathrm{d}$, e means with different superscripts on same row differ significantly $(\mathrm{p}<0.05)$.

$*=$ significant $; \mathrm{ns}=$ not significant

The observed improvement $(\mathrm{p}<0.05)$ in weight gain of the broiler chicks fed $\mathrm{T}_{4}$ might be due to the presence of supplementary wheat offal. Addition of $2.5 \%$ wheat offal and $7.5 \%$ Amaranthus spinosus leaf meal improve feed intake suggesting that was not the reason for the trend of feed intake. This agrees with the findings of Ahaotu et al. (2012), Uwalaka et al. (2013), Price (2008) and Berganza et al. (2003) that consumption of high fibre diets resulted in significant $(p<0.05)$ increase in feed intake. The result of the organ weight characteristics of the broiler chicks is shown in Table 3. The result showed that Amaranthus spinosus leaf meal and wheat offal had no significant $(p<0.05)$ effect on heart and kidney weights. This finding is in agreement with the reports of Ahaotu et al. (2013b), Bressani et al. (1993) and Brenner et al. (2000). These authors observed significant $(\mathrm{p}<0.05)$ improvement in heart girth of broiler chicks with increased dietary energy density.

Table 3

\section{Effects of Amaranthus spinosus leaf meal diets on organ weight characteristics of Hubbard broiler chicks.}

\begin{tabular}{lcccccc}
\hline \hline Heart girth & $9.86^{\mathrm{a}}$ & $9.53^{\mathrm{b}}$ & $9.52^{\mathrm{b}}$ & $10.80^{\mathrm{b}}$ & $11.80^{\mathrm{c}}$ & $1.90^{*}$ \\
Liver & 2.37 & 2.37 & 2.39 & 2.41 & 2.45 & $0.08^{\mathrm{ns}}$ \\
Heart & 0.60 & 0.59 & 0.68 & 0.70 & 0.72 & $.06^{\mathrm{ns}}$ \\
Kidney & 0.48 & 0.46 & 0.47 & 0.49 & 0.52 & $0.09^{\text {ns }}$ \\
Gizzard & 3.38 & 3.39 & 3.37 & 3.59 & 4.01 & $0.03^{\text {ns }}$ \\
\hline \hline
\end{tabular}




\section{CONCLUSION}

Amaranthus spinosus leaf meal and wheat offal supplementation in broiler chicks diets produce positive results in broiler chick production at $7.5 \%$ inclusion rate. It also enhances the productivity and feed conversion ratio of broiler chick rearing. For optimizing the profits from broiler production, $A m$ aranthus spinosus leaf meal and offal may be incorporated to the diets of commercial starter broilers.

\section{REFERENCES}

[1] Ahaotu, E. O., Kwushue, V. and Ahaotu, Esther, O. (2018a): Performance implications of feeding different levels of pawpaw (Carica papaya) leaf meal on finisher broiler birds. Journal of Poultry Science and Technology. $6(1), 1-4$.

[2] Ahaotu, E. O, Amadinze, C., Ahaotu, Esther. O. (2018b): Carcass and organ weight indices of feeding different levels of pawpaw leaf meal (Carica papaya) on finisher broiler birds. Journal of Meat Science and Technology. 6 (1), 1-4.

[3] Ahaotu, E. O., Ekenyemm B. U. and Aggrey, E. (2017): Sustainability of sweet orange (Citrus sinensis) peel meal on the performance of finisher broilers. J. Agric. Sci. Pract. Vol. 2. pp. 27-32.

[4] Ahaotu, E. O., Okonkwo, V. N., Okorie, K. C. and Akinfemi, A. (2016a): Effect of bambara nut sievate supplemented exogenous enzymes on haematology and serum biochemical value of finisher broiler birds. Book of Proceedings of Academic Conference on Positioning Sub-Saharan Africa for Development in the New Development. 22-23rd June, 2016, Cambridge Hall, University of Ghana, Legon Campus, Accra, 9 (1), 32-39.

[5] Ahaotu, E. O., Okonkwo, V. N., Ihenacho, R. A and Ebochuo, V. C. (2016b): Performance and carcass characteristics of finisher broilers fed brewer's dried grain supplemented with exogenous enzymes. Book of Proceedings of Academic Conference on Positioning Sub-Saharan Africa for Development in the New Development. 22-23rd June, 2016, Cambridge Hall, University of Ghana, Legon Campus, Accra, 9 (1), 200-208.

[6] Ahaotu, E. O., Adeyeye, S. A. and Okonkwo, V. N. (2015): Replacement value of sweet orange (Citrus sinensis) peels for wheat offals in the performance of broiler starter diets. Scientific Journal of Animal Science. 4 (3), 42-50. Doi: 10.14196/sjas.

[7] Ahaotu, E. O.. Ezeafulukwe, C. F., Ayo-Enwerem C. M. and Ekenyem, B. U (2013a): Effects of enzyme fortified raw moringa seed (Moringa oleifera) waste diets on nutrient utilization and haematological parameters of broilers. Inter J Appl Sci Engr, 1 (1), 25-30.
[8] Ahaotu, E. O, Umoh, G., Onwueagba, A. E., Chukwu, A. O. and Iwuanyanwu, U. P. (2013b): Guinea Fowl Keets performance under improved and extensive conditions in Athony and Patience Farms, Atta - Ikeduru, Imo - State, Nigeria. Inter J Agri Biosci, 2 (2), 82-86.

[9] Uwalaka, R. E., Ihezuo, J. P. and Ahaotu, E. O. (2013): Effects of inclusion of unripe plantain peel meal (Musa paradisca) on carcass quality, performance and internal organ weights in finisher broiler birds. Inter J Agri Biosci, 2 (4), 136-140.

[10] Ahaotu, E. O; Edih, M. C; Onuruka, A. U; .Ehirim, V. I. and Sirimongkolkasen, A. (2012): Effects of replacement of soyabean (Glycine max) with pigeon pea (Cajanus cajan) in starter broiler ration. International Journal of Tropical Agricultural and Food Systems, 6 (1). 40-44.

[11] Akinfemi, A., Ayoade, J. A., Ahaotu, E. O. (2014): Changes in the proximate composition and in vitro digestibility of fungal treated rice straw. Proc. 39th Conf., Nig. Soc. for Anim. Prod. 16-19 March, 2014, pp. 313-315.

[12] Berganza, B. E., Moran A. W., Rodrigez G. M., Coto N. M., Santamaria M. and Bressani. R. (2003): Effect of variety and location on the total fat, fatty acids and squalen content of amaranth. Plant Foods Hum. Nutr. 58, 1-6.

[13] Brenner D. M., Baltensperger D. D., Kulakow P. A., Lehmann J. W., Myers R. L., Slabbert M. M, and Sleugh B. B. (2000): Genetic resources and breeding of amaranthus. In: Janick J. (ed), Plant Breeding Reviews, volume 19. John Wiley \& Sons INC, NY, 229-238.

[14] Bressani R., De Martell, E. C. M. and De Godinez C. M. (1993): Protein quality evaluation of amaranth in adult humans. Plant Foods Hum. Nutr. 43, 123-43.

[15] Gordon, S. P and Gordon, F. S. (2004): Contemporary Statistics: A Computer Approach. Mc.Graw - Hill Publishers, U.S.A.

[16] Imo State Ministry of Lands and Survey (IMLS) (2009): Longitudes and Latitudes locations of Umuagwo, Ohaji / Egbema Local Government Area of Imo State, Nigeria.

[17] Okonkwo, V. N. and Ahaotu, E. O. (2014): Effects of cassava pulp sievate meal on hematological indices of finisher broiler birds. World Journal of Agricultural Sciences. Vol. 2 (6), pp. 142-145.

[18] Ononiwu, C. C, Ahaotu, E. O, Okonkwo, V. N., Ayo-Enwerem, C. M. and Botchway, H. (2017): Effects of bambara nut sievate fortified exogenous enzyme on performance and carcass characteristics of finisher broiler birds. Proceedings of the 20th Biennial Conference, Ghana Society of Animal Production (GSAP), 1-5 August, 2017. Sasakawa Centre, University of Cape Coast, Ghana, pp. 73-80.

[19] Price, M. L (2008): Amaranthus grains and Vegetable types. Echo Technical Notes. 83, 1-15,

[20] Steel, R. C, and Torrie, J. H, (1980): Principles and Procedures of Statistics. A Biometrical Approach, $3^{\text {rd }}$ Edition. Mc Graw Hill Book; N.Y., U.S.A. 